\title{
'Darling, It Is Entirely My Fault!' Gordon Brown's Legacy to Alistair and Himself
}

\author{
David Coates \\ Department of Political Science, Wake Forest University, PO Box 7568, Reynolda Station, \\ Winston-Salem, NC 27109, USA. \\ E-mail: coatesd@wfu.edu
}

Gordon Brown's 10-year stint as Chancellor of the Exchequer can and should be tested. He claimed full success in his 11th and final budget statement. We find success to be more partial. We find an impressive record on growth, employment and inflation. We also find weaknesses on productivity growth, size of the manufacturing sector, debt levels, transport systems and housing provision; and serious shortcomings in policy on poverty and inequality. We see difficulties with the underlying growth model: persistent weaknesses on wages, hours of work, work-induced stress levels and the development of work-based skills. We see a need for significant policy change, but doubt its impending arrival.

British Politics (2008) 3, 3-21. doi:10.1057/palgrave.bp.4200078

Keywords: Gordon Brown; new growth theory; performance indicators; third way politics

\section{Introduction}

It is rare to be given so clean a run at the legacy of a major politician as that now allowed to us by Gordon Brown's 10-year period as Chancellor of the Exchequer. ${ }^{1}$ It could not be tidier: a straight decade to measure, an allpowerful Treasury to watch, and a clear division of authority (between the man and his prime minister) to clarify the lines of responsibility. Gordon Brown came to No. 11 with a critique and a mission. He laid both out as he arrived, and he measured his own achievement against them as he left. It is a measurement that we too can make. We can start with his assessment and then supplement it with our own. That supplementary process is never easy or without controversy. Isolating the impact of policy is more difficult than politicians often claim or commentators normally allow (for a full discussion of this problem, and an earlier assessment of Brown's Chancellorship, see Coates, 2005a, Chap. 8), but even so we can ask 'did Gordon Brown work?': and we should, for Brown, far more than Blair, has been the architect of the domestic dimensions of the 'third way' project of which he is now the unchallenged leader. The strengths and weaknesses of Brown, the Chancellor, stand a fair 
chance of being replicated by Brown, the premier: so we need to know exactly what those strengths and weaknesses are - the better to extract what is valuable from the Brown programme and to argue for the discarding of what is not.

\section{Brown's Claim}

Gordon Brown gave his first budget speech on 2 July 1997. He gave his last on 21 March 2007. In the first he said this.

The impact of the global market in goods and services, and of rapidly advancing technology, is now being felt in every home and in every community in our country. New products, new services, new opportunities challenge us to change: old skills, old jobs, old industries have gone and will never return. The dynamic economies of the future will be those that unlock the talent of all their people, and our creativity, our adaptability, our belief in hard work and self improvement. The very qualities that made Britain lead the world in the 18th and 19th centuries, and precisely the qualities we need to make Britain a strong economic power in the 21 st century. But to achieve that we must address the four weaknesses that have held us back for too long and for too many years - instability, under-investment, unemployment and the waste of talent (Budget Speech, reprinted in The Guardian, 3.7.97, emphases added).

To address those four weaknesses, the new Chancellor immediately handed over responsibility for the setting of interest rates to the Bank of England, retaining for the Treasury only the capacity to set the inflation target to which the Bank should work. He introduced his own 'New Deal' for the young unemployed, began to lower taxation on the corporate sector and held out the promise of a sustained reskilling of the UK labour force. He would later supplement that with boosts to R\&D expenditure designed to close the UK's productivity gap with its major international competitors, and with public sector initiatives (increases in public spending, public-private finance schemes and public service agreements) designed to enhance the quantity and quality of the UK's welfare services (see Coates, 2005a, b). He also, in that first budget, began to reset tax codes in ways that helped working families and alleviated poverty - if only by stealth; but only and always within two newly adopted and regularly publicised rules.

My first rule - the golden rule - ensures that over the economic cycle the Government will borrow only to invest and that current spending will be met from taxation. My second rule is that, as a proportion of national income, public debt will be held at a prudent and stable level over the economic cycle (The Guardian, 3.7.97). 
The question we can now ask is whether the pursuit of those programmes within rules of this kind did then bring the stability, investment, employment and innovation that the incoming Chancellor claimed that they could. His own judgement, a decade later, was that they had, and in some measure. This is the same Chancellor in 2007.

In this, my eleventh budget, my report to the country is of rising employment and rising investment, continuing low inflation and low interest and mortgage rates....

- The British economy is today growing faster than all the other G7 economies... the years of sustained growth [that] will continue into its 59th quarter — the forecast end of the cycle — and then into its 60th and 61st quarter and beyond....

- Before 1997 we were bottom in the G7 for national income per head...now we are second only to America....

- Since 1997 inflation has averaged... half that of the previous decade... Britain's best inflation performance for a century....conditions for maintaining the low interest and mortgage rates that since 1997 have been half the... average of the previous twenty years...

- We will never return to the old boom and bust. Ten years ago and for decades before, Britain's stop-go economy was also held back by chronic underinvestment, the lowest investment of the G7. Now alongside North America's, Britain has the G7's fastest growing business investment rising in real terms by $48 \%$ since $1997 \ldots$

- As a result of sustained growth and investment we have closed the productivity gap with Japan and Germany, have narrowed it with America and halved it with France.

- It is now almost forgotten that in past decades Britain suffered higher unemployment not only than America and Japan but than France, Germany and the rest of Europe. But today, with unemployment falling and 2.6 million more in work, Britain has a higher proportion of men and women in employment than America, Japan and all our major European neighbours (Chancellor of the Exchequer's Budget Statement, 21.3.07).

Eleven budgets built on 'monetary discipline [as] the foundation of economic strength', and 'fiscal discipline [as] the foundation of the strength of Britain's finances'. Eleven budgets that, year on year, mixed incentives for work and investment with tax changes for prosperity and social justice. Eleven budgets, each and every one of which, as Gordon Brown put it in 2007, had been designed 'for Britain's families, for fairness, and for the future'. The question before us is whether that design worked. 
6

\section{Surface Success}

On the surface of things, and in important ways, the first answer to that question has to be 'yes'. The achievement has been considerable, and has been recognised as such by external auditors as disparate as the Organisation for Economic Cooperation and Development (OECD) and the European Union (EU) Commission. Indeed, the OECD famously hailed the UK in 2006 as "the new goldilocks economy... neither too hot nor too cold... the right porridge recipe, strong growth and low inflation' (The Guardian, 12.3.07; also see 9.5.06). New Labour's record on economic growth, inflation, unemployment and living standards is as the Chancellor described it.

The UK economy had been growing steadily for 15 quarters when Gordon Brown arrived in No. 11, and it has continued to grow, quarter on quarter, ever since. The result has been an unprecedented period of unbroken economic expansion, all the more remarkable since no other major industrial economy including the United States - has been able to match the stability of its growth record (though some have exceeded its rate). ${ }^{2}$ The rate of growth has ebbed and flowed, and sections of the economy (particularly manufacturing) have known brief periods of recession; but the economy as a whole has not. It grew $3.9 \%$ in $2000,2.3 \%$ in $2001,1.8 \%$ in $2002,2.2 \%$ in $2003,3.3 \%$ in $2004,1.8 \%$ in $2005,2.5 \%$ in 2006 and it is still growing. Consumer spending has been the largest single driver of that growth throughout; but lately business investment has played its part too - and is currently strong. Investment in UK-based companies rose $6.9 \%$ in the last quarter of 2006 , a quarter in which the UK passed China (to become second only to the United States) in the volume of Foreign Direct Investment attracted, some $£ 78$ billion (although most of this was for acquisitions and mergers rather than new plant and equipment).

This has also been a period of economic growth unaccompanied by rapid price inflation - growth, that is, without overheating. The inflation rate over which Margaret Thatcher's Chancellor, Geoffrey Howe, presided peaked at $18 \%$ in 1980. Even John Major's Chancellor, Kenneth Clarke, faced inflation rates as high as 3.5\% in March 1993. But not Gordon Brown: under his stewardship of the UK economy, the rate of inflation hovered, month by month, either side of the far lower $2 \%$ target he had set, and spent significant periods of that 10 years under the target rather than above it. When inflation in the UK spiked at 3\% in December 2006, that spike constituted an 11-year high - the average rate between 1997 and 2004 was a mere 1.9\% (The Guardian, 2.5.05). This, in a period in which real living standards rose, for the broad mass and generality of the UK population, in a regular and unprecedented fashion: $14 \%$ on average between 1997 and 2000, with a further $6 \%$ gain by 2004 . The growth in personal consumption triggered by New Labour brought gross domestic product (GDP) per head in the UK up close to (or even surpassing) 
those prevalent in Germany, France, Sweden and Japan, and closed the gap significantly on average living standards prevalent in the United States (see Coates, 2005a, 169; also see Prime Minister's Strategy Unit, 2005, 13).

When Gordon Brown arrived at No. 11, unemployment stood at 2,040,000: a rate of $7.2 \%$. The rate of youth unemployment was even higher: $13.7 \%$ (Nickell, 1999, 14). None of that now applies. Unemployment fell in an unbroken fashion from 1997 to 2004, and though it then rose, the rate has yet to exceed 5.6\% under New Labour (or 1.7 million people in total); and the economy has absorbed an extra 2.6 million workers while keeping unemployment low, as the Chancellor correctly claimed in 2007. The unemployment rate in the UK throughout Gordon Brown's time in No. 11 was similar to those in the US and Japan, and was significantly below the rates that were common in Germany, France and the OECD as a whole. ${ }^{3}$ In February 2005, the UK unemployment rate was actually the lowest in the G7; as an economy which in 1986 had seen unemployment peak at 3.1 million (10.6\% of the labour force) 20 years later, on comparable data, had unemployment at less than one million (and a rate of $3 \%$ ).

\section{Persistent Problems}

Not everything in the UK economic garden, however, has been, or is, rosy. New Labour ministers know that, and make no secret of their knowledge. On their own figures, serious problems remain on the productivity front, in the performance of UK-based manufacturing industries, and in the staffing and delivery of frontline welfare services. The unemployment figures too obscure as much as they illuminate.

The long-established productivity gap between the UK economy and its major industrial competitors is still in place, in spite of a decade of sustained Treasury attention and periodic bouts of active intervention by the Chancellor himself. When Gordon Brown arrived at No. 11, the UK's trend rate of labour productivity was just over $2 \%$. It subsequently rose to $2.59 \%$ (Treasury/DTI, 2006, 1): but that still left UK labour productivity by 2007 some $15-30 \%$ lower than that of its major competitors (Prime Minister's Strategy Unit, 2005, 16). Moreover, the UK economy narrowed its productivity gap on France and Germany under New Labour less by increasing its rate of output per hour than by maintaining its position as a long-hours, low-unemployment economy. The figure for average annual hours worked in the UK in 2002 stood at 1,669. That total was lower than in 1997: but it was still significantly higher than the figure for Germany $(1,426)$, France $(1,441)$ and Sweden $(1,585)$ (Mishel et al., 2007, 334). Output per worker in the UK did finally manage to exceed that in Germany by 2005, but even then the average German worked 6 weeks less each year than his or her UK equivalent, and produced almost as much 
8

(The Guardian, 25.4.05). After a decade of New Labour in power, the average French worker still produced $19 \%$ more per hour than the average UK worker; the average American produced 16\% more and the average German 15\% more. Of the major industrial economies in 2005, only Japan had a significantly lower rate of output per hour - $17 \%$ lower than the UK figure. In the relevant league table, the UK in 2005 ranked 15th out of 27 in the OECD as a whole: a ranking that, for all the policy initiatives and sophisticated Treasury reports of the Brown years at No. 11, had not significantly changed since 1997.

That was partly because the UK manufacturing sector continued to shed labour while Gordon Brown was at the Treasury - employment continued to shift from the primary and secondary sectors into the tertiary one - and economies with a large service sector find productivity leaps of the kind Gordon Brown required hard to generate. Brown did maintain a strong productivity pressure on the public sector, as we will see next, but without any significant improvement in the output per hour there. Productivity in the service sector is notoriously hard to measure - in public welfare provision, it is doubly so - but what measures we have suggest a possible decline in public sector productivity - certainly that has been the claim for the health sector not a rise. ${ }^{4}$

What is easier to see is the state of the UK manufacturing sector. Under New Labour, that sector did not enjoy stable growth. It was briefly in recession in 2001 and again in 2004; and it shed labour in significant volume both when contracting and when expanding. As late as 2004, manufacturing output remained at or below its 1998 level, output produced in 2004 from a labour force cut by more than one million since New Labour came to power. Not until August 2007 did manufacturing output in the UK economy regain the levels it enjoyed before the 1992 sterling crisis. It is the service sector, not manufacturing, that now provides two-thirds of all employment in the UK, with financial services alone accounting for $4.1 \%$ of all jobs and $8.5 \%$ of GDP. The manufacturing sector, by contrast, has seen its share of GDP fall from over $20 \%$ in 1997 to less than $15 \%$ today.

It is true, of course, that the UK manufacturing sector contains pockets of world excellence - particularly in the new knowledge-based industries that straddle manufacturing and services - but overall the rate of innovation in manufacturing has been low, and the sector's 'record on R\&D and patents [since 1997 has been] comparatively weak' (Prime Minister's Strategy Unit, 2005, 20). ${ }^{5}$ Michael Porter, brought to the UK in 2003 by the DTI to report on the state of manufacturing industry, was particularly critical of UK company performance on $R \& D$ expenditure: noting that 'the $R \& D$ gap [was] increasing: [and that] the UK was one of the few advanced economies in which business spending on R\&D ha[d] fallen relative to GDP in the 1990s' (Porter and Ketels, 2003, 36; Coates, 2005a, 101-108). The pattern of productivity growth 
(and associated prosperity) is also highly uneven regionally. Currently only four of the top 50 high-productivity regions in the UK economy lie outside London and the English east and south-east (Local Futures Group, 2006). Whatever else Gordon Brown's policies have or have not delivered thus far, an expanded manufacturing sector has not been one of them (see Coates, 2005a, 173-178). Nor has there been any abatement of the long-established NorthSouth divide. Under-performance on both these dimensions of economic performance remains a major concern.

So too does the tension within the New Labour project on how best to reset the delivery of public services. Partly the problem here has been political. How best to reform the health service was a major area of disagreement between the Blairites and the Brown supporters, a clash of views and personalities that overshadowed in the minds of many voters the common agreement of both factions to spend more on education, health and welfare. The Blairite enthusiasm for deepening choice by extending market processes and consumer power within the public sector existed alongside (and in tension with) Gordon Brown's enthusiasm for the targeting of productivity increases through public service agreements. ${ }^{6}$ Their twin assault brought dissatisfaction among health workers and school teachers - two key Labour voting blocs - to new heights by 2007 , dissatisfaction which the Chancellor's insistence on wage settlements at or below inflation only intensified. New Labour found itself spending more and more on public services, only to trigger mounting industrial unrest and voter indifference ${ }^{7}$ : not quite the outcome either Blair or Brown anticipated when they launched their expanded and reformed public services during New Labour's second term.

And as Brown moved from No. 11 Downing Street to No 10, a number of the more conventional economic indicators awaiting his successor at the Treasury began suddenly to darken. The inflation rate quickened, ${ }^{8}$ and wage settlements started to rise ${ }^{9}$; unemployment approached pre-1997 levels ${ }^{10}$; and criticism intensified around key Brown initiatives. The true cost of PFI remained highly contentious. ${ }^{11}$ So too did the impact of New Labour's welfareto-work programme - its 'New Deal'. Critics of the New Deal have long claimed that the fall in youth unemployment normally attributed to it was largely illusory: illusory either because that fall would have happened anyway, ${ }^{12}$ or illusory because the fall in unemployment numbers had quite simply not occurred. ${ }^{13}$ The Department of Work and Pensions has its own defense against these charges ${ }^{14}$; but both sides of the argument recognise that, as unemployment rates have fallen, the number of people claiming disability benefit in the UK has gone up: less a movement off the welfare rolls than a movement from one form of welfare to another. ${ }^{15}$ It is also the case that longterm unemployment remains an unresolved problem, and that the labour market participation rate, though high, is still only at $74 \%{ }^{16}$ 
So for all the claims about a job well done, in truth serious problems loomed as the Brown years as Chancellor came to a close. They were problems that were sufficiently visible to key sections of the UK electorate as to deny Brown as premier the chance to seek a renewed mandate through an early general election. ${ }^{17}$ They were problems that derived from three features of the Brown record at the Treasury that are often glossed over, but which we need now to explore in some detail: problems linked in part to the success of the Brown programme, in part to its failures, and in part to the character of the underlying growth theory on which the programme rests.

\section{Insecure Foundations}

The problems now looming before New Labour are partly those of rising affluence anchored on insecure foundations. Living standards rose steadily under New Labour in large measure because UK consumers regularly spent more than they earned, and what they bought far exceeded in volume and value the level of overseas purchases of the things they themselves made. New Labour-induced affluence, in the first decade of their period of power, rested, that is, on debt. It was not public debt. Gordon Brown did hold to his golden rule, and kept public debt within prudent limits, a prudence anchored in the generous tax revenues created by economic growth itself. Labour-induced affluence rested rather on high levels of personal debt and a huge trade imbalance.

The figures on personal indebtedness in Gordon Brown's UK are striking. Total credit card and mortgage debt in the UK crossed the $£ 1$ trillion mark for the first time in May 2006 - an amount larger than the whole external debt of Africa combined - and personal bankruptcies rose in 2006 to 107,000: up 59\% on the record 2004 figure of 67,000. By December 2005 almost two million people in the UK owed more than $£ 10,000$ on credit cards, overdrafts and other unsecured loans; and half a million of those had unsecured debts in excess of $£ 20,000$. (BBC News, 17.4.06. The New Statesman called this 'The Debt Pandemic' in a cover story with that title (24.10.05). The pandemic intensified in 2006.) Their indebtedness helped the UK to a position of leadership which the New Labour Government would no doubt like to lose: its position as the debt capital of Europe. A third of all unsecured loans in continental Europe in 2005 were held by British borrowers: the product of a 'buy now, pay later' culture fueled by the existence of more than 50 million UK credit cards (The Guardian, 27.9.06), and a culture that left many 18-40 year olds in particular in genuine financial stress. ${ }^{18}$ Interest rates are currently low - though those on credit card loans are much higher than the average, of course - but even now the number of people seeking debt counseling is continuing to grow. (The Citizens Advice Bureau reported a record 1.7 million 
people seeking debt counselling in 2006, up $20 \%$ on the year before. BBC News, 11.9.07.) What will happen to those people should interest rates rise rapidly is hard to quantify, but it is unlikely to be pleasant.

The figures on the size of the UK's overseas deficit under New Labour are equally daunting, if less immediately threatening to the capacity of New Labour to generate continued economic growth. In 2006, the UK's deficit on overseas trade in goods hit a new peak of $£ 84.3$ billion, more than $5 \%$ of GDP (the manufacturing trade deficit was $£ 7$ billion in 1997 , but nearly $£ 60$ billion a decade later). Service exports then pulled the overall deficit down to around $3.5 \%$. In March 2007, 'the UK imported $£ 7$ billion more goods than it exported - more than 6\% of GDP' (The Guardian, 14.5.07). The Treasury is well aware of the potential dangers here - documents issued with each budget regularly address the imbalance (see, e.g., HM Treasury, 2007, Ch. B, paras 83-86) - but policy-makers seem committed to the view that foreign investment flows will continue to make up the shortfall. Let us hope they are right. It is certainly not obvious to everyone that, over the long term, that position is sustainable (for the view that it is not, see Elliott and Atkinson, 2007). At the very least, current levels of personal and overseas debt, taken together, put a huge question mark over the adequacy of the foundations and long-term stability of UK economic growth, a question mark that policy has yet adequately to address.

Along the way, the low interest rates and easy borrowing associated with sustained economic growth have also compounded problems inherited in 1997 and only now bubbling to the top of the political agenda. One is the rising tide of alcoholism and obesity associated with high consumer spending, particularly amongst the young. New Labour came into power decrying the 'yob' culture of the Thatcher years; but it has now generated its own, against which it directs an ineffective hail of Anti-Social Behaviour Orders. In New Labour Britain, people are eating out and drinking in as never before, ${ }^{19}$ and the effects are showing - primarily on the waistlines of the affluent and their children. An OECD report published in 2006 reported the British as now the fattest men and women in Europe. The Government's own figures have two-thirds of British men and almost $60 \%$ of British women as overweight; and forecast that a third of all children under 11 are likely to be overweight by 2010 (The Guardian, 11.10.06).

The UK is not alone, of course, in facing problems of obesity. Obesity is an issue for all affluent car-based societies in the first decades of the new millennium. What is particular to the UK, however, is the extent to which the ever accelerating consumption of cars has not been matched since 1997 by road construction of an equivalent scale: so that transport gridlock now looms on many of the UK's major motorways and in its main urban areas. Thirty-two million vehicles driving around on just over 2,000 miles of main highway makes 
the UK one of the least car-friendly economies in the advanced industrial world. ${ }^{20}$ Ministers know that, and are currently projecting an extra six million cars on UK roads by 2031. But that volume of additional cars would fill the M25 many times over; and New Labour has yet to find a way of squaring the necessary road-building programme with the concerns of its environmentalist and conservation lobbies. The interface of transport needs and environmental concerns looms as a genuine policy conundrum for New Labour in its second decade in power.

The difficulty of parking in urban areas is then compounded by the perpetual 'in filling' of ever smaller houses in those same urban areas, as New Labour-induced affluence hits its other roadblock: that of an inadequate supply of affordable housing. Total house starts in 2006 - at 168,000 - were less than half the post-war peak: the 350,000 new houses built in 1968. By 2007, in seven out of 10 of the UK's 517 largest towns and cities, house purchase is now beyond the capacity of the nation's teachers, policemen, firefighters and nurses - the comparable proportion in 2002 had been just over a third (BBC News, 13.4.07). More than half of all university graduates under 40 currently find themselves unable to get on to the property ladder (The Guardian, 6.10.07), shut out of the housing market by an inflationary spiral that reached an annual rate of $11 \%$ in 2006 (a rate almost unchanged, at $11.1 \%$, by June 2007). Prices rose at the remarkable rate of $£ 41$ a day in November 2006, to take the average cost of a home in the UK to just over $£ 200,000$. Faced with that price explosion, a whole generation of first time buyers has been obliged since 1997 to tolerate a higher ratio of salaries to mortgage, and an elongation of the mortgage loan itself: taking on extra debt and risk, only then to be vulnerable to any tightening of interest rates or subsequent house price collapse. Interest rates have tightened, and are likely to tighten still more, as the Bank of England's Monetary Policy Committee continues to struggle with its own resulting and insoluble dilemma: of how to slow down the housing market while maintaining employment and investment in the rest of the UK economy. House prices too fell in September 2007.

Building the necessary houses is now a key feature of New Labour policy under Gordon Brown; but the solution can only compound the financial fragilities associated with overheated housing markets. By the end of 2006, and before any substantial new house building is under way, UK mortgage debt exceeded the value of the UK's total GDP by $26 \%$, and total household debt (including mortgage debt) exceeded GDP by $64 \%$ - a ratio of household debt to GDP that has risen by 50 percentage points since 2000 alone (Financial Times, 5.10.07). Ratios of that magnitude leave UK economic growth rates particularly vulnerable to shortfalls in the flow of funds to the housing market of the kind triggered by the sub-prime loan crisis of the summer of 2007. That crisis has already obliged Alistair Darling to concede that 'Britain's economy 
will be hit by the global credit squeeze, forcing the government to downgrade its growth forecasts' (ibid.). 'Blair and Brown rarely mention the inflationprone housing market, the trade deficit or the stagnation of manufacturing when they laud their own economic successes' (The Guardian, 10.5.07). They don't, but we certainly should.

\section{Serious Shortfalls}

But not all the problems looming for New Labour in its second phase were a product of policy successes in its first. Serious shortfalls in achievement between 1997 and 2007 will also set the agenda for New Labour under Brown.

One particularly sensitive area for the incoming prime minister has to be poverty and inequality. His Chancellorship was marked by persistent attempts to 'redistribute by stealth' — via annual tax changes that sent extra resources to the poor and disadvantaged. This redistribution strategy existed alongside more public and explicit commitments to the poor: the introduction of a minimum wage, and an unprecedented commitment to the abolition of child poverty by 2020 . But commitments and achievements - stealthy or otherwise - are never the same thing, and they certainly weren't in this case. The complexity and stealth of the budget initiatives militated against their full-take. In fact take up was, in an entirely predictable fashion, least among the very groups most in need. The minimum wage was always set low, generosity here taking second place to the job creation/small business expansion goals of Brown's general policy. ${ }^{21}$ And as Chancellor, Gordon Brown proved entirely unwilling to curb high salaries - sharing with Blair a willingness to let top salaries soar: both men apparently subscribing to a sort of social democratic 'trickle down theory' of wealth creation. ${ }^{22}$ Both the Chancellor and the poor are now paying the price of that parsimony. Poverty in the UK is a relative measure, of course: so as inequality rises, so too does poverty. The data on both are startling. Ten years of Brown as Chancellor have seen inequality, at best, stabilise and poverty first fall and then begin once more to rise.

The data here are so damning — and so indicative of tasks yet to be addressed - that they are worth bringing into the body of the text. Three things at least are clear.

- 'Labour's decade in power has failed to reverse the surge in inequality under Margaret Thatcher, and Gordon Brown's policies to support the less well-off are failing to prevent the gap between rich and poor widening again' (The Guardian, 18.5.07). Without Brown, inequality may well have increased $^{23}$ : with him, it has, at most, stabilised at Thatcherite levels. Indeed, there is now recent evidence that the gap between rich and poor may even be widening again, as top incomes soar (Financial Times, 
22.6.07). ${ }^{24}$ Certainly, the Gini coefficient for 2005-2006 was 'statistically significantly higher than that which the Labour Government inherited' (Brewer et al., 2007, 1); and the Joseph Rowntree Foundation reported in July 2007 that the gap between rich and poor in the UK is as wide now as at any time in the last four decades (see http://www.jrf.org.uk/pressroom/ releases/170707.asp).

- Poverty is again on the rise. The number of people living in poverty in the UK (measured as living on less than $60 \%$ of average incomes) did fall steadily from 1997 to 2004 - from 14 million to 12.1 — but it rose again in 2005 to 12.7 million (incomes for the bottom $10 \%$ of the UK population grew by only $7 \%$ between 2000 and 2006: income for the top $10 \%$ rose by twice that percentage). Moreover, the current poverty figure - £217 a week - leaves more than 1.5 million people living in households with incomes that are within $£ 10$ of it: over 14 million people, that is, currently in or on the edge of poverty (Brewer et al., 2007; The Guardian, 2.4.07).

- That rise in poverty included children. New Labour's flagship target - the eradication of child poverty - took a serious hit in 2005/2006. The number of children in poverty that year increased: to 3.8 million from 3.6 million. Indeed, when UNICEF issued its seventh report on child poverty in rich countries, it placed the UK 18th out of 21 on a composite scoring of all six measures that it used, and actually last on two of them. ${ }^{25}$ That, in the same year in which a major study by the National Children's Bureau found that a child born to a labourer was still six times more likely to suffer extreme poverty by age 30 than was a child born to a lawyer; and that children born into disadvantaged families in 2000 had slipped further behind their middle-class equivalent by the age of 3 than had those born in similar positions of disadvantage in the 1970s (The Observer, 2.9.07).

So poverty and inequality remain to be tackled, and so too do skills. Good new growth theorist that he is, Brown knows the importance of investment in human capital. He came into office reluctant to re-impose compulsory industrial training boards. He preferred to socialise the costs of re-skilling, via Individual Learning accounts and a new University of Industry modelled on the Open University. Both those initiatives quickly failed, however, and were abandoned: replaced in centrality by a Blairite push for 'No Child Left Behind': the raising of general standards of numeracy and literacy through the regular testing of school children and the public dissemination of the resulting pattern of school performance. But that too has had only limited impacts on skill levels, and a distorting impact on the school curriculum, not to mention on stress levels among teachers and pupils alike. After a decade of New Labour policies, the UK adult labour force remains under-skilled and undercredentialised in comparative terms; and Brown knows that. Blair's 1996 
mantra was 'education, education, education'. Brown's 2007 mantra — for a world in which Chinese, Indian and Brazilian economic power looms - will inevitably have to be 're-skill, re-skill, re-skill': a job worth doing, but one not done yet on anything like the scale required. ${ }^{26}$

\section{Darling's Dilemma}

There is more - problems that are deeper still — problems rooted in New Labour's underlying strategy for achieving economic growth. These are often attributed to Brown the personality: Scottish, Presbyterian, dour, the micromanager, even the control freak. They would be more properly attributed to a particular reading of the requirements of new growth theory and an understanding of strategies of 'progressive competitiveness' - a reading of the role of the state in an age of globalisation, that is, as no longer one of 'picking winners' but rather that of playing a 'lubricating' and 'enabling' role in the establishment of national competitive advantage (Coates, 2000, 254).

Gordon Brown is no advocate of old-style social democratic 'tax and spend'. $\mathrm{He}$ is prepared to spend (on public services) — he is not a neo-liberal conservative - but he is adamant that such spending should only come out of tax revenues generated by economic growth. Large-scale capital expenditure needed for catch up, on his model, has to be raised in joint ventures between the state and private finance: and the rate of return on that investment has to be guaranteed by ever intensified work routines in the public sector itself. 'Squeezing' public sector productivity out of expanding public services whose capital investment is partly privately advanced is a core feature of the Brown model: his way of squaring low taxation with better public services. But it is a model that then comes with a price - a price of increasing work loads, work stress and diminished rewards/unit of output across the public sector as a whole. The adverse industrial relations and electoral fall out of such a model is already visibly considerable.

This intensification of the work-effort bargain has been matched, for the private sector, by an insistence on flexible labour markets: by a steady refusal - by Gordon Brown no less than by Tony Blair — to allow any strengthening of the collective role of labour in the management of UK industry. Brown regularly advocates the reform of the European social model (see for example Brown, 2005, 11), and is an ardent defender of the UK's right to opt out of its labour market dimensions: from the Working Time Directive to the insistence on worker directors. Brown the father of young children has grown more sensitive to the needs of working mothers - a sensitivity there from his first budget (when he triggered a national child care strategy) and one which has grown and widened over time (to his public support of the Prosser Report, and his advocacy of wrap-around schooling. See also Coates and Oettinger, 2007). 
But we should not expect more than that. The Brown Government will no doubt continue to make it easier for people with children to stay at work longer - normally by paying other women to look after the children so abandoned but it is unlikely to provide the scale of expenditure (and hence taxation) necessary for adequate and affordable child-care nationwide. ${ }^{27}$

Nor is it likely to address the reconstitution of the capital-labour accord in the UK in favour of a low-hours, high-investment solution to the problem of squaring the quality of home life with the competitiveness of the workplace. The basic asymmetry of New Labour's relationship with capital and labour will be at its most visible here in the future, as it has been in the immediate past. We can expect from the Brown Government, as we received from the Blair ones, no direction of capital, no state-funding of business ventures, no limits on top salaries and benefits; but also no extensive new rights (collective or otherwise) for individuals as they work, no obligation on private employers to provide adequate child care facilities, and no explicit state challenge to the continuing reality of a gender-based glass ceiling. Gordon Brown spent his last days as Chancellor talking of the need for 'continuity and change'. Pitching himself as the new leader, he put the emphasis on change: but there will be continuity too. Massive continuity, probably, in these key areas of life under New Labour: the continuation in accentuated form, of the very features of the UK labour market that so eroded support for Thatcherism and brought New Labour to power.

In 1997, wage levels in the UK were low by the best European standards, and income inequality was high. That is still the case. The IFS calculated in 2006 that inequality remained unchanged in the period from 1997 to 2006, primarily because of rising incomes for the top $20 \%$ of wage and salary earners. In 1997, UK workers worked longer hours than their European counterparts, ${ }^{28}$ and experienced significant levels of work-related illness and stress. They still do. ${ }^{29}$ When New Labour came to power, the skill levels of the average UK worker were low, by German and Scandinavian standards at least - and they still are. The total picture is therefore bleak but clear. New Labour policies under Gordon Brown as Chancellor worked less well than is often claimed; but New Labour voters did not. They worked harder than ever under New Labour in its first phase; and unless policy changes dramatically in its second, they are yet likely to end up working harder still.

\section{Conclusions}

The question therefore becomes: can policy change in ways that will tackle underlying weaknesses of the kind enumerated here? The need is obvious but the capacity is not. Even if the will to change was there, the space for change is likely to prove illusive. As the new Chancellor of the Exchequer, Alistair 
Darling finds himself seriously limited in what he can do by projections and commitments put in place in Gordon Brown's last budget in 2007. He finds himself boxed in by the difficulty of making sharp changes of policy without de-legitimising all that has gone before; and his capacity for independent action has to be constrained by his own involvement - as a junior Treasury minister in 1997 - in the design and implementation of policy lines from which he would now do well to break. If anything, he is now hostage to the overambitious forecasts for economic growth and welfare spending with which Gordon Brown closed out his tenure of the Treasury. Its new incumbent used his first pre-budget report (in October 2007) to scale down projected rises in public spending between now and the next general election: just $2.2 \%$ a year now for education and $3.7 \%$ for health. $3.7 \%$ is short of the $4.4 \%$ rate of spending increase advocated in the Wanless Report, and only half the $7.2 \%$ annual rate of growth of health spending that Gordon Brown himself advocated in 1999.

Alistair Darling is also boxed in by the sheer difficulty of easing one set of problems without compounding difficulties in another set. It would be hard, for example, for any new Chancellor right now to persuade the Bank of England to lower interest rates to stimulate borrowing for industrial investment, since such a move would inevitably overheat the housing market still further. By the same token, it will be difficult for the new Chancellor to fund major increases in transport provision without threatening the supply of public funds to antipoverty programs; and it will be difficult for him to generate a rapid supply of new housing without hitting skills shortages in the building trade, and without adding adversely (through its impact on consumer demand) to the economy's already enormous trade deficit. Gordian knots are difficult to cut, particularly ones quietly and cumulatively created by a Chancellor-Prime Minister so publicly convinced of the rightness of his cause.

Yet Gordian knots do need to be cut; and the rule is clear: the tougher the knot, the tougher the cut. Knots created by third way policies will not be unraveled by them. They need sharper steel. Change of a fundamental kind is visibly needed if the precarious base on which New Labour's economic prosperity now rests is not to be progressively exposed over time. An earlier Labour Government dealt with productivity issues in the public sector by building a social contract with public sector unions of the kind hinted at in the agreement struck between Tony Blair and the unions at Warwick in the run up to the 2005 general election. Old Labour met its winter of discontent in 1979 only because it reneged on that contract. Paradoxically, New Labour under Brown runs the risk of a similar clash with public sector workers because it has no contract to sign. A little more corporatism, and a little less new growth theory, might yet enable Gordon Brown to avoid Jim Callaghan's fate. And if not that, then at least a string of policy commitments that the Brown 
Government currently has not made: including a more active industrial policy; a new 'golden rule' to limit the rate of appreciation of sterling; policies designed to raise UK worker rights to the best European norm; an effective relocation policy to counter the north-south divide; a commitment to fair trade, not free trade, between the EU and its major trading partners; and a progressive tax code that rewards success at the bottom and punishes failure at the top.

Such changes in policy are, of course, all defining elements of that 'fourth way' in UK economic policy against which so far New Labour has chosen to set its face. But Gordon Brown is only prime minister because his predecessor fell victim to the sin of hubris - in Blair's case, hubris in relation to Iraq. It will be a great pity if the Brown premiership turns out to be brief because of a similar hubris, this time in relation to economic rather than to foreign policy.

\section{Notes}

1 I am grateful for comments on an earlier version of this article from anonymous reviewers, and from colleagues attending the British Politics Group panel at the 2007 APSA Conference in Chicago, especially Wyn Grant, Terence Casey, Chris Howell and Jim Cronin.

2 The Governor of the Bank of England put it this way in May 2007. 'In short, the behaviour of the UK economy has improved over the past decade, both in terms of its performance and its stability, and that improvement has been more marked in the United Kingdom than in the rest of the G-7'. This is in Mervyn King, The MPC Ten Years On (lecture to the Society of Business Economists, 2.5.07).

3 In 2006, for example, the standardised rate for the UK was 5.5\%, for the US 4.6\%, Japan $4.1 \%$, France $8.9 \%$, Germany $8.4 \%$ and the Euro-Area as a whole $7.4 \%$. See National Institute Economic Review, No. 199, 2007, 18, 21 and 25.

4 The Office of National Statistics announced in October 2004 that productivity in the NHS has probably fallen by up to $1 \%$ a year since 1997 . See Coates (2005a, 237, n. 54).

5 In 2004, the OECD ranked the UK alongside Australia and Ireland in the third rank out of four in its assessment of innovation.

6 The running of the NHS was and remains a real political football. Gordon Brown used his Social Market Foundation address in 2003 to discuss the limits of markets in health care, triggering an immediately hostile response from the then Health Secretary, Alan Milburn. Frank Dobson, Alan Milburn, John Reid and Patricia Hewitt all saw their political careers damaged or terminated because of their performance as Health Secretary: sequentially struggling with administrative re-organisations, failing hospitals, job cuts and pay restraint.

7 Unison voted in April 2007 to ballot its 450,000 members on industrial action up to and including strikes, in protest at Gordon Brown's imposition of a below-inflation $2 \%$ pay increase on public sector workers. Civil servants struck for 24 hours in January 2007, in protest over job cuts, privatisation and pay. 1.5 million local authority workers followed suit in March - the biggest national one-day stoppage since the 1980s. The General Secretary of the Commercial and Public Service union warned Gordon Brown in May that he could face 'a summer of discontent'. See The Guardian, 17.5.07.

8 The UK inflation rate broke through the 3\% barrier in March 2007 (it fell back to $2.8 \%$ in April). The MPC of the Bank of England responded with its fourth consecutive interest rate rise 
- taking UK interest rates to a six-year high of 5.25\%, above those of the other G7 economies. See Financial Times, 14.5.07).

9 Pay deals began to rise in parallel, settling at their highest for five years. A third of the deals reported in the first quarter of 2007 averaged more than $4 \%$ (BBC News, 11.5.07).

10 Unemployment in the UK rose in the first quarter of 2007, to 1.7 million. It fell back to 1.68 million in April 2007. The Government's preferred measure of unemployment — people available for work - rose by 13,000 in the quarter, as the number in work fell by 55,000.

11 Public sector unions in education, health and transport remain fiercely opposed to PFI, treating it as backdoor privatisation and excessively expensive. Even the Committee on Public Accounts joined in with its own critique in May 2007. The fullest academic critiques are in Leys, 2001; and Pollock, 2004; also see Coates, 2005: 120-24.

12 A 4-year assessment by Richard Blundell and colleagues concluded that the New Deal for young people had raised employment by 17,000 a year, rather than the 375,000 figure used by the government. See Dickens et al. (2003, 17).

13 In May 2007 Frank Field released a scathing critique of the performance of Gordon Brown's New Deal, calling it 'woeful', pointing out that there were more young people (18,000 more) currently out of work than when the scheme began in 1998, and that one in three New Deal recipients were repeat participants (Press Release, Frank Field website).

14 And they are not alone in that. For a more positive assessment of Labour's welfare-to-work programs, see Brewer and Shephard (2004).

15 Sheffield Hallam University researchers located 1.7 million 'hidden unemployed' in the UK in 2007, one million of them tucked away on disability benefit. They calculated real unemployment as stable during New Labour's second term, at 2.6 million.

16 Of the 950,000 people claiming Jobseekers Allowance in November 2006, 100,000 had spent 6 of the last 7 years on benefits (BBC News, 17.12.06).

17 There was a moment, during the week of the Labour Party conference in 2007, when speculation on a 1 November election was rife. The case for it was in part the recognition that serious problems loomed that could cost New Labour votes if the election was delayed particularly a potential 'winter of discontent' by disaffected public sector workers. But the bigger immediate issue - the one that blocked the election gamble — was clear polling evidence of lack of public support for New Labour policies in key marginal constituencies. New Labour under Gordon Brown's Chancellorship may have been economically successful: but progressively New Labour has found that success hard to turn into votes. In October 2007, New Labour stood 3 percentage points behind the Conservatives in the Ipsos/Mori poll conducted for the Sun newspaper.

18 The plight of 18-40 year olds in the UK debt culture has recently been documented by a Financial Services Authority/Bristol University study published in March 2006. Help the Aged criticised the study for ignoring the needs of old people. Old and young alike, it appears, are struggling with unprecedented high levels of personal debt in Gordon Brown's UK.

19 Consumer spending in the UK hit a record $£ 1.09$ trillion in 2006. Forty per cent of that spending was on property and $23 \%$ on holidays. The next largest item was alcohol: $19 \%$ of the total (The Guardian, 16.5.07).

20 The proportion of roads congested (with delays lasting an hour or more) is currently $25 \%$ in the UK. It is less than $20 \%$ in Spain, less than $10 \%$ in Germany and less than $5 \%$ in France (Financial Times, 11.1.07). The ratio of motorway miles to population in the UK is the third worst in Europe, better only than Ireland and Greece.

21 The latest increase in Minimum Wage (in September 2007) was a mere 17p, taking it from $£ 5.35$ an hour to $£ 5.52$. The increase for workers $16-21$ was $16 \mathrm{p}$ ( $£ 4.44$ to $£ 4.62$ ). These are not large amounts, although at $3 \%$ are marginally more generous than the $2 \%$ limit fixed for public sector pay. 
22 Prior to the 2001 election, Blair was on record as being indifferent to wealth inequalities: a view he later recanted (in an interview with the Labour journal Progress, March 2005). His government toyed with legislation on top salaries in 2004, but then backed off. The ratio of top pay to average wages in the UK was 25:1 in the mid-1980s. It is now close to 100:1. Directors' salaries in the FTSE 100 rose $28 \%$ in 2005, as average earnings rose just $3.7 \%$. Bonuses in the city that year rose to 16\% (Financial Times, 6.11.06; The Guardian, 17.8.06 and 3.10.06).

23 This is certainly the claim in the Government's own audit (Prime Minister's Strategy Unit, 2005, 52 ), that 'modeling shows that inequality would have been substantially greater in $2002 / 3$ had the 1996/7 system remained unchanged'.

24 Boardroom pay in the UK's top companies rose by $37 \%$ in 2006,11 times faster than average earnings and nearly 20 times faster than the rate of inflation of the consumer price index (The Guardian, 29.8.07).

25 The six measures (with the UK ranking) were material well-being (18), health and safety (12), educational well-being (17), family and peer relationships (21), behaviours and risk (21) and subjective well-being (20) (see UNICEF, 2007, 2).

26 The Government's own audit in 2005 reported that ' $34 \%$ of working-age UK citizens still lack a level 2 qualification (down from $40 \%$ in 1997) and $15 \%$ still lack any qualification (down from $18 \%$ in 1997). In $2003,54 \%$ of UK $25-28$ year olds held a level 3 or higher qualification - up from $47 \%$ in 1998 , but still lower than the $62 \%$ in France and the $74 \%$ in Germany.....70\% of the job growth by 2009 is projected to need skill level 3 or above' (Prime Minister's Strategy Unit, 2005, 29-30).

27 At least New Labour, thanks to Gordon Brown's tax changes, does have a 10-year national child-care strategy, which aims to have affordable child care available for children under 14; and we have seen significant improvements in statutory maternity (and optional paternity) pay. But the pressures on working families are such that women in the UK return to work on average when their baby is just 21 weeks old; and $95 \%$ report feelings of guilt at leaving their children in nurseries or with child-minders. The length of the average UK father's working week is $10 \%$ higher than the EU norm; child-care places remain scarce and expensive in many UK towns and cities, especially in the south-east; and the quality, wages and training of child care assistants remains dismal. See The Guardian, 28.1.06.

28 Data on hours worked goes in two directions. Formal hours are falling: down in 2004 to 37.1 from 38.9 in 1994. But unpaid overtime persists for at least $20 \%$ of the labour force particularly senior managers and teachers - with surveys suggesting that maybe as high as $80 \%$ of UK workers take work home at the weekend. Certainly, $63 \%$ of all UK bosses and team leaders failed to take their full holiday entitlement in 2005, and even when they did, they regularly checked their e-mails and voicemail. No wonder then that John Carvel was able to report that British men are currently 'making themselves ill by over-working....one in three relies on alcohol to switch off from job stress... 17\% have visited a doctor to discuss their exhaustion' (The Guardian, 6.6.06).

29 Work-related stress (about heavy workloads, long hours and the threat of redundancy) is now the biggest source of complaints at work. The TUC, whose 2004 survey found $58 \%$ of its officers reporting stress as their major agenda item, estimated the annual cost to the UK economy (in sick pay, lost productivity and NHS bills) at $£ 7$ billion (The Observer, 31.10.04). HSE data confirm the TUC case, but prices it differently: 13 million working days lost at the cost of $£ 3.8$ billion.

\section{References}

Brewer, M., Goodman, A., Muriel, A. and Sibeta, L. (2007) 'Poverty and inequality in the UK: 2007', The Institute for Fiscal Studies, Briefing Notes BN73. 
Brewer, M. and Shephard, A. (2004) Has Labour Made Work Pay? York: Joseph Rowntree Foundation.

Brown, G. (2005) Global Europe: Full-Employment Europe, London: HM Treasury.

Coates, D. (2000) Models of Capitalism: Growth and Stagnation in the Modern Era, Cambridge: Polity Press.

Coates, D. (2005a) Prolonged Labour: The Slow Birth of New Labour Britain, London: Palgrave.

Coates, D. (2005b) 'Campaigning in poetry, governing in prose', Harvard University Center for European Studies, Working Paper Series 123.

Coates, D. and Oettinger, S. (2007) 'Two Steps Forward, One Step Back: The Gender Dimensions of Treasury Policy under New Labour', in C. Annersley, F. Gains and K. Rummery (eds.) Women and New Labour, Bristol: Polity Press.

Dickens, R., Gregg, P. and Wadsworth, J. (2003) The Labour Market Under New Labour, London: Palgrave.

Elliott, L. and Atkinson, D. (2007) Fantasy Island, London: Constable.

HM Treasury DTI. (2006) Productivity in the UK 6: Progress and New Evidence, London: HMSO, March 2006.

HM Treasury. (2007) The Economy, Financial Statement and Budget Report, London, www. hm-treasury.gov/uk.

Leys, C. (2001) Market-Driven Politics, London: Verso.

Local Futures Group. (2006) State of the Nation 2006, www.localfutures.com.

Mishel, L., Bernstein, J. and Allegretto, S. (2007) The State of Working America 2006/7, Ithaca: Cornell University Press.

Nickell, S. (1999) 'Unemployment in Britain', in P. Gregg and J. Wadsworth (eds.) The State of Working Britain, Manchester: Manchester University Press.

Pollock, A. (2004) NHS:plc, London: Verso.

Porter, M. and Ketels, C. (2003) 'UK competitiveness: moving to the next stage', DTI Economics Paper No. 3, London.

Prime Minister's Strategy Unit. (2005) Strategic Audit: Progress and Challenges for the UK, London: Cabinet Office.

UNICEF. (2007) Innocenti Report Card 7 (Child Poverty in Perspective: An Overview of Child Well-being in Rich Countries), Florence: UNICEF. 